\title{
Life Cycle Assessment of Building Renovation Measures-Trade-off between Building Materials and Energy
}

\author{
Ricardo Ramírez-Villegas ${ }^{1,2} * \mathbb{C}$, Ola Eriksson ${ }^{2}$ (D) and Thomas Olofsson ${ }^{3}$ \\ 1 School of Technology and Business Studies, Dalarna University, 79188 Falun, Sweden \\ 2 Faculty of Engineering and Sustainable Development, University of Gävle, 80176 Gävle, Sweden; \\ ola.eriksson@hig.se \\ 3 Department of Applied Physics and Electronics, Umeå University, 90187 Umeå, Sweden; \\ thomas.olofsson@umu.se \\ * Correspondence: rrv@du.se; Tel.: +46-(0)243-5595-00
}

Received: 19 December 2018; Accepted: 21 January 2019; Published: 23 January 2019

\begin{abstract}
The scope of this study is to assess how different energy efficient renovation strategies affect the environmental impacts of a multi-family house in a Nordic climate within district heating systems. The European Union has set ambitious targets to reduce energy use and greenhouse gas emissions by the year 2030. There is special attention on reducing the life cycle emissions in the buildings sector. However, the focus has often been on new buildings, although existing buildings represent great potential within the building stock in Europe. In this study, four different renovation scenarios were analyzed with the commercially available life cycle assessment software that follows the European Committee for Standardization (CEN) standard. This study covers all life cycle steps from the cradle to the grave for a residential building in Borlänge, Sweden, where renewable energy dominates. The four scenarios included reduced indoor temperature, improved thermal properties of building material components and heat recovery for the ventilation system. One finding is that changing installations gives an environmental impact comparable to renovations that include both ventilation and building facilities. In addition, the life cycle steps that have the greatest environmental impact in all scenarios are the operational energy use and the building and installation processes. Renovation measures had a major impact on energy use due to the cold climate and low solar irradiation in the heating season. An interesting aspect, however, is that the building materials and the construction processes gave a significant amount of environmental impact.
\end{abstract}

Keywords: life cycle assessment; building renovation; district heating; environmental impacts; energy efficiency; climate change; energy directive; building materials

\section{Introduction}

The European Union has the ambition to reduce energy use in buildings by $30 \%$ and greenhouse gas emissions (GHG) by $40 \%$ by 2030, compared to 1990 [1]. Within the EU, buildings currently account for $40 \%$ of total energy use and 36\% of total GHG emissions [2]. In Sweden (EU member), the construction and real estate sector accounts for about $40 \%$ energy use, but only $15 \%$ of GHG emissions. The lower share of GHG is mainly due to the extensive use of renewable energy sources in the heating and electricity sector [3].

An estimate is that $80 \%$ of the buildings used today will remain in 2050 [4]. This means in a longer perspective, more buildings will be for renovation than new constructed buildings [5]. Based on the EU ambition to reduce GHG emissions for the construction and real estate sector, the need to improve 
energy efficiency for existing buildings is urgent. In addition, from a holistic perspective of renovation proposed by the European Commission, the life cycle approach is necessary [4].

Sweden has a special situation regarding its energy system. Primarily, the electricity supply is from renewable sources and nuclear power. In addition, approximately $90 \%$ of Sweden's multi-family houses rely on city-based district heating $(\mathrm{DH})$ systems [6]. This creates a reduction in heating demand in Sweden, with DH systems mainly using renewable fuels. Thus, there are no environmental advantages from a marginal perspective, if electricity consumption increases [7-9]. Furthermore, it is important to note that a large share of the Swedish building stock (constructed during the Millennium Program from the 1960s to the beginning of the 1970s) has a relatively good standard, compared to many other EU member countries $[10,11]$. Nevertheless, reducing energy use in these buildings is interesting, although the challenges in the Nordic climate go beyond the typical approaches and therefore need special attention.

In order to achieve overall improvements in GHG emissions, life cycle thinking has increased in recent years. Previously, the focus on buildings' energy efficiency was merely on the energy use during operation of a building. However, the focus has shifted to include the embodied environmental impacts of a building [12]. Standardization has played an important role in introducing life cycle assessment (LCA) in the building construction industry [13]. As part of the trend, a CEN standard specifies performance of LCA on buildings. Based on that standard, the commercially available OneClickLCA software is available for practitioners. There is little or no research on the usefulness of such tools. In addition, increased awareness among various actors has made LCA an integral part of Building Environmental Assessment tools like BREEAM, LEED and Miljöbyggnad. The latter is the most widely used method for building environment certification in Sweden [14-16]. Reza et al. [17] claim that LCA helps to provide results that are more transparent for decision makers and other stakeholders.

According to a study by Cabeza et al. [18], LCA research often applies so-called "ex-exemplary buildings". This means that the majority of research includes buildings that already intended to be more environmentally friendly, while there is little or no research on conventional buildings. According to Vilches et al. [4], the relationship between embodied environmental impacts and operational has changed in a way that when buildings become more energy efficient, the embodied impact increases in percentage. Nevertheless, the building energy use affects the global warming potential (GWP) [19]. Recent studies have shown that the life cycle utilization of a conventional building contributes $62-80 \%$ of the total GWP, while a low-energy building contributes $54-91 \%$ of the total GWP (9). Wallhagen et al. [20] has shown the importance of life cycle-based calculations as a decision tool for new buildings. Mjörnell et al. [21] has developed a decision tool to help property owners and practitioners make decisions when they face major renovations. Studies in Nordic climate investigated differences of materials used in high-rise buildings, as in Skullestad et al. [22]. Earlier studies investigating renovation of commercial buildings can be exemplified by Lasvaux et al. [23]. Dodoo et al. [24] showed that renovation of existing multi-family houses in Sweden can gain significant life cycle savings. Akander et al. [7] studied how different renovation strategies could be more economically viable. It is apparent that improvements in building heating and ventilation and air conditioning systems (HVAC) are more economically feasible than improvements in building performance. It can result in up to $20 \%$ energy savings. Swing et al. [8] found that renovation measures reduce the total energy use, but do not necessarily reduce the use of total primary energy use in a Swedish context. Häflinger et al. [25] showed the importance of sensitivity analysis of different types of materials, which can result in significant different results depending on the modelling. Roux et al. [26] performed a building's LCA with climate change scenarios and the development of the French energy mix. It showed that these future scenarios have a major impact on LCA results. Schlanbusch et al. [27] studied LCA's challenges and needs from a Nordic perspective. Wijnants et al. [28] studied life cycle environmental impacts for open renovation systems for single-family houses and Oviir [29] studied the LCA impact on the Estonian building standard. 
In short, previous research on energy efficiency measures and LCA are limited to different types of buildings with a particular focus on newly built energy-efficient housing. Studies on renovation are scarce. In addition, previous research is scattered. Previous studies have investigated all possible improvements and increased efficiencies for different types of buildings in different climate zones, with different effects, such as energy savings, cost savings, primary energy, GHG and more. Few studies have focused on the increased relative importance of building materials with reduced energy use and when clean energy is used. However, in earlier research conducted by Lidberg et al. [30] and Ramírez-Villegas et al. [31], assessing energy-efficient renovation in multi-family houses was applied in a DH district. We believe that it is of global interest to gain insight into how different renovation strategies can affect the environmental impact of multi-family houses in large-scale DH in a low-carbon context. Therefore, the scope of this study is to:

1. Assess renovation strategies comprising energy efficiency measures for a relatively high standard multi-family house in the Nordic climate, in a low-carbon DH system, where demand for space heating during the cold winter is substantial.

2. Include environmental impact for both building construction materials used for renovation and operational energy savings.

3. Apply a life cycle analysis in accordance with the CEN standard and discuss methodological implications.

By doing this, the study will complement the energy-efficient renovation assessment methodology proposed. Furthermore, the result can contribute to a more complete assessment for building renovation.

\section{Methods}

The method of this study is described in line with the ISO standard for Life Cycle Assessment [32].

\subsection{Objectives}

\subsubsection{Goal}

The two-fold goal is to:

1. Investigate how different renovation strategies affect the life cycle environmental impact with respect to materials and operational energy use.

2. Identify and discuss how the different life cycle stages contribute to the total environmental impact for these renovation strategies.

\subsubsection{Functional Unit}

The functional unit selected for this study is the entire building use over a period of 50 years. The building is a three-story residential building in the municipality of Borlänge, Sweden $(250 \mathrm{~km}$ Northwest of Stockholm). The building is located in an area called "Tjärna Ängar", built within the years 1969-1971, during a period in Sweden called the Million Homes Program. The selected building is a three-story building with 36 apartments and a total heated area of $2822 \mathrm{~m}^{2}$ (Figure 1). In addition, after renovation of the same building, with an improved energy efficiency for the next 50 years, it serves as the reference study period. 


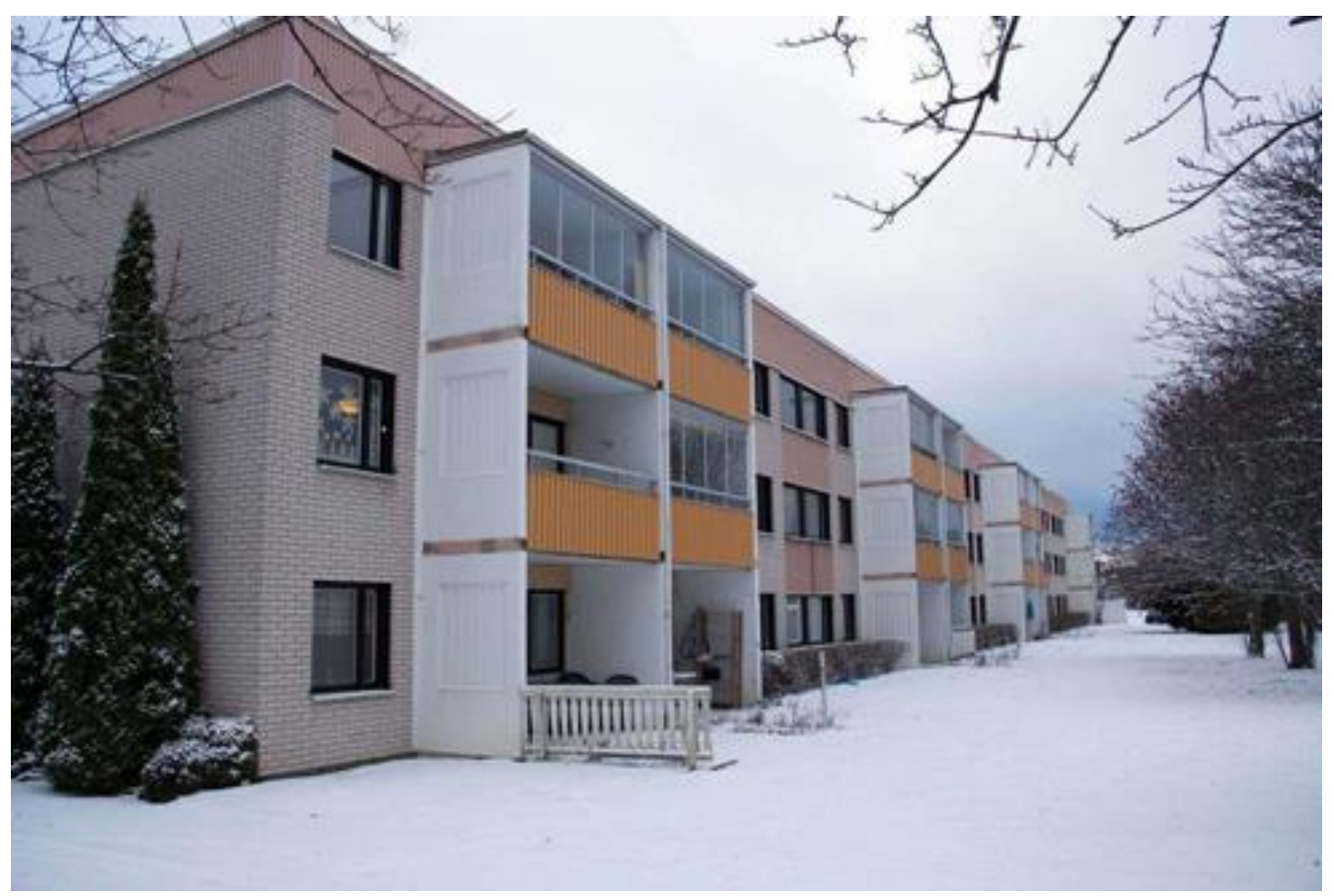

Figure 1. Case study building.

\subsubsection{System Boundaries}

This study encompasses all phases from cradle to grave according to the standard EN 15978; manufacture of construction materials (A1-3), construction processes (A4-5), use (B1-7) and end of life (C1-4). In addition, the benefits and loads beyond the system boundary (D) were calculated, but not included in the total results.

The study complies with the standard EN 15978 [33]. That means it is considered as an attributional LCA, i.e., in this case, bookkeeping of the environmental impact for renovation of a specific building during the reference study period. At the same time, different renovation strategies are considered (see scenarios below), suggesting the study to be used in decision-making. The discussion section includes a further elaboration of this contradiction.

\subsection{Scenarios}

This study assessed four different renovation scenarios (defined in [31]): deep energy renovation scenario (DEERS), building envelope scenario (BEnS), heat recovery ventilation scenario with reduced indoor temperature (HRV21) and heat recovery ventilation scenario without reduced indoor temperature (HRV22.7). Scenarios reflect different strategies that are more or less material-intensive in addressing the issue of the relative importance of the material to energy in terms of environmental impact. Information about the scenarios are presented in Table 1.

Table 1. Investigated refurbishment packages.

\begin{tabular}{|c|c|c|c|c|c|}
\hline Building Part & As Built & DEERS & BEnS & HRV22.7 & HRV21 \\
\hline External Walls & $\begin{array}{l}120 \mathrm{~mm} \\
\text { mineral wool } \\
\text { insulation }\end{array}$ & $\begin{array}{l}480 \mathrm{~mm} \\
\text { mineral wool } \\
\text { insulation }\end{array}$ & $\begin{array}{l}480 \mathrm{~mm} \\
\text { mineral wool } \\
\text { insulation }\end{array}$ & As Built & As Built \\
\hline Unheated Attic & $\begin{array}{l}150 \mathrm{~mm} \\
\text { mineral wool } \\
\text { insulation }\end{array}$ & $\begin{array}{l}300 \mathrm{~mm} \\
\text { mineral wool } \\
\text { insulation }\end{array}$ & $\begin{array}{l}300 \mathrm{~mm} \\
\text { mineral wool } \\
\text { insulation }\end{array}$ & As Built & As Built \\
\hline Windows & Double casement & $\begin{array}{l}3 \text { glass argon filled low } \\
\text { emissivity pane }\end{array}$ & $\begin{array}{l}3 \text { glass argon filled low } \\
\text { emissivity pane }\end{array}$ & As Built & As Built \\
\hline Ventilation system & Mechanical & Heat Recovery & Mechanical & $\begin{array}{c}\text { Heat } \\
\text { Recovery }\end{array}$ & $\begin{array}{c}\text { Heat } \\
\text { Recovery }\end{array}$ \\
\hline Indoor temperature & $22.7^{\circ} \mathrm{C}$ & $21^{\circ} \mathrm{C}$ & $22.7^{\circ} \mathrm{C}$ & $22.7^{\circ} \mathrm{C}$ & $21^{\circ} \mathrm{C}$ \\
\hline
\end{tabular}


The chosen renovation scenarios reflect the measures usually applied in the renovation of buildings in Sweden. That means that they are technically, and to a varying extent, economically viable in the general perception of the construction and real estate sector. The chosen renovation scenarios were determined to reduce purchased energy for buildings. The first scenario called DEERS is a scenario earlier applied in the residential area Brogården (Alingsås, Sweden) [34]. The building conversion scenario BEnS is a variation of the previous scenario but without considering changes in installations. The last two scenarios HRV22.7 and HRV21 consider upgrading of installations rather than the physical properties of the building. The temperature reduction in HRV21 takes into account the assumption that preheated supply air increases the thermal comfort in the building.

\subsection{Life Cycle Inventory}

\subsubsection{Material Use}

Data from similar projects conducted by a building construction company quantified the material use of the different renovation scenarios [35]. In Tables 2-7 all used data are compiled. In the selected software used, the datasets adopted are product-specific environmental product declarations (EPD). Where more than one EPD is available, the one more significant for the local market was adopted. When no EPDs where available, generic data from Ecoinvent and GaBi were adopted. All the EPDs contain expenditures of cradle-to-grave or cradle-to-gate stage, according to EN 15804 and EN 15978 standards.

The "As Built" scenario assumed that all exhaust ventilation components would need replacement. To reflect the potential impact of material production in the selected country, compensation of data from other countries was according to the CEN/TR 15941 method. All building materials data (windows, insulation, walls and facade) are data from building construction companies. All information related to installations (heating systems, ventilation systems) is general data from the software manufacturer [36]. All transport distances are average data from the Nordic countries and are defined in the program as standard (60 km, trailer combination 40 tonnes, $100 \%$ filling rate). All upstream data are from the Ecoinvent and the GaBi databases.

Table 2. As built dataset.

\begin{tabular}{ccccc}
\hline Resource & Quantity & Unit & Service Life & Country \\
\hline Ventilation exhaust unit & 3 & pcs & 25 years & France \\
\hline
\end{tabular}

Table 3. DEERS dataset.

\begin{tabular}{ccccc}
\hline Resource & Quantity & Unit & Service Life & Country \\
\hline Dry mortar & 71,800 & $\mathrm{~kg}$ & As building & Norway \\
Gypsum plasterboard & 1198 & $\mathrm{~m}^{2}$ & As building & Norway \\
Mineral wool. Insulation & 1198 & $\mathrm{~m}^{2}$ & As building & Denmark \\
Radon and moisture membrane 1,2 MM & 1198 & $\mathrm{~m}^{2}$ & 30 years & Norway \\
Calcium silicate block 115 MM & 1198 & $\mathrm{~m}^{2} \mathrm{~m}$ & As building & Germany \\
Min. wool insul. for pitched roof 300 MM & 971 & $\mathrm{~m}^{2}$ & As building & Denmark \\
Triple glazed windows, wood-alum. frame & 298 & $\mathrm{~m}^{2}$ & 40 years & Norway \\
Heating system & 2822 & $\mathrm{~m}^{2}$ & As building & Finland \\
Ventilation system & 2822 & $\mathrm{~m}^{2}$ & 30 years & Finland \\
Heat Recovery Ventilation unit & 1 & $\mathrm{pcs}$ & 25 years & Germany \\
\hline
\end{tabular}


Table 4. BEnS dataset.

\begin{tabular}{ccccc}
\hline Resource & Quantity & Unit & Service Life & Country \\
\hline Dry mortar & 71,800 & $\mathrm{~kg}$ & As building & Norway \\
Gypsum plasterboard & 1198 & $\mathrm{~m}^{2}$ & As building & Norway \\
Mineral wool insulation & 1198 & $\mathrm{~m}^{2}$ & As building & Denmark \\
Radon and moisture membrane, 1,2 MM & 1198 & $\mathrm{~m}^{2}$ & 30 years & Norway \\
Calcium silicate block 115 MM & 1198 & $\mathrm{~m}^{2}$ & As building & Germany \\
Min. wool insul. for pitched roof 300 MM & 971 & $\mathrm{~m}^{2}$ & As building & Denmark \\
Triple glazed windows, wood-alum. frame & 298 & $\mathrm{~m}^{2}$ & 40 years & Norway \\
Heating system & 2822 & $\mathrm{~m}^{2}$ & As building & Finland \\
Ventilation system & 2822 & $\mathrm{~m}^{2}$ & As building & Finland \\
Ventilation exhaust unit & 3 & $\mathrm{pcs}$ & 25 years & France \\
\hline
\end{tabular}

Table 5. HRV 21-22.7 dataset.

\begin{tabular}{ccccc}
\hline Resource & Quantity & Unit & Service Life & Country \\
\hline Heating system & 2822 & $\mathrm{~m}^{2}$ & As building & Finland \\
Ventilation system & 2822 & $\mathrm{~m}^{2}$ & 30 years & Finland \\
Heat Recovery Ventilation unit & 1 & $\mathrm{pcs}$ & 25 years & Germany \\
\hline
\end{tabular}

\subsubsection{Energy Use}

All renovation scenarios were investigated based on simulation. The building energy simulation (BES) tool was IDA-ICE (version 4.7.1. EQUA Simulation AB, Solna, Sweden) [37]. More details about the BES can be seen in [31]. Based on the available data, it is possible to assess the environmental impact of the building's energy use. The selected scenarios affect the energy use of the building differently, either by reducing active heat demand or by introducing more efficient installations. The assumption in this study was that energy use would be the same for the building over the next 50 years.

Table 6. Fuel use (\%) for DH 2016 [38].

\begin{tabular}{ccc}
\hline Fuel Use (\%) & Borlänge Energi & Göteborg Energi \\
\hline Recycled energy & 67 & 70.4 \\
Industrial Excess Heat & 20 & 29.7 \\
Flue Gas Condensing & 1.6 & 11.1 \\
Heat from Heat Pumps (Netto) & 0.5 & 5.7 \\
Municipal Solid Waste (MSW) Incineration & 44.3 & 23.9 \\
Blast Furnace Gas & 0.6 & 0 \\
Renewable energy & 30.7 & 9.9 \\
Pellets, Brickets and powder & 0 & 1.3 \\
Secondary biofuels & 28.6 & 4.3 \\
Bio oil and tall oil pitch & 0 & 0.2 \\
Renewable electricity & 2.1 & 4.2 \\
Others & 1.2 & 2 \\
Hot water from other companies, renewables and recycled energy & 1.2 & 2 \\
Fossil energy & 1.1 & 17.7 \\
Oil & 1.1 & 0.2 \\
Natural Gas & 0 & 17.5 \\
\hline
\end{tabular}

Table 7. Greenhouse gas emissions (GHG) emission factors for DH 2016 [38].

\begin{tabular}{ccc}
\hline GHG Emissions $\left(\mathrm{G} \mathrm{CO}_{\mathbf{2}} \mathbf{e q} / \mathbf{k W h}\right)$ & Borlänge Energi & Göteborg Energi \\
\hline Total Emissions & 66 & 79 \\
Combustion & 62 & 69 \\
Fuel transport and production & 4 & 10 \\
\hline
\end{tabular}

The building is located in Borlänge, Sweden. The municipality DH system provides space heating and domestic hot water preparation. Waste incineration with energy recovery and industrial excess 
heat is the main source. The estimated total use is $360 \mathrm{GWh}$ of heat per year. Because the used software only allows verified data in an EPD, the nearest possible verified data set, when it comes to data on emissions, was from Göteborg Energy Partille Ale, compare Tables 6 and 7.

It is noticeable that there is a difference between the amounts of fossil fuels used in the various DH systems. Consequently, there is a need to use only externally verified data in the software. This affects the results that show a higher environmental impact.

\subsection{Life Cycle Impact Assessment}

According to the EN15978:2012 standard [33], using the CML2002 Impact Assessment Method developed by the University of Leiden is required [4]. In this study, four relevant impact categories are considered; global warming potential (GWP), acidification potential (AP), eutrophication potential (EP) and abiotic depletion potential of non-fossil elements (ADP). The relevance of these effects in the Swedish context is the basis for the choice of impact categories. GWP is the most relevant impact globally, due to the large amount of research, partly by the IPCC [39]. It reflects the fact that human-based GHG emissions have a major impact on the climate. ADP and EP are part of what Rockström et al. [40] defined as "planet boundaries". They play an important role in minimizing negative environmental impacts. Finally, ADP is relevant because of the importance of changing from energy efficiency to resource efficiency.

\section{Results}

The effect of energy efficiency measures during the operational phase for the building scenarios was determined with simulations, using the BES tool IDA-ICE. DEERS is the scenario that reduced the energy use most. The reduction was $43 \%$, compared with the original building. BEnS and HRV21 scenarios reduced energy use by $27 \%$. HRV22.7 is the scenario with the lowest reduction, $15 \%$. Based on the energy performance of the different scenarios, the reductions in buildings' lifetime energy use were similar, see Table 8.

Table 8. Energy use per year for the renovation scenarios.

\begin{tabular}{cccccc}
\hline Indicators & As Built & DEERS & BEnS & HRV 22.7 & HRV 21 \\
\hline DH use $\left(\mathrm{KWH} / \mathrm{M}^{2}\right)$ & 141 & 81 & 105 & 120 & 100 \\
Electricity use $\left(\mathrm{KWH} / \mathrm{M}^{2}\right)$ & 11 & 6 & 6 & 9 & 9 \\
DH use reduction $(\%)$ & & 43 & 26 & 16 & 29 \\
Electricity use reduction $(\%)$ & & 45 & 45 & 18 & 18 \\
Heating demand $\left(\mathrm{W} / \mathrm{M}^{2}\right)$ & 115 & 49 & 72 & 88 & 77 \\
Heating demand reduction \% & & 57 & 37 & 24 & 33 \\
\hline
\end{tabular}

With these results of energy savings, along with information on the use of building materials from the building construction company, it was possible to determine environmental performance for both energy and material use of the proposed scenarios in the selected categories.

As shown in Figure 2, all renovation options result in a reduction of GWP. This is mainly due to the reduction of energy use during the lifetime. The presented results are GWP savings compared to the original building. In this category, DEERS is the scenario with the lowest GWP impact. It reduced the GWP of energy use by $42 \%$ and had a total GWP saving of $19 \%$ compared with the original building. HRV21 is the second scenario, with savings of $23 \%$ of $\mathrm{CO}_{2}$ eq compared with the original building and total savings of $16 \%$. Scenario HRV 22.7 reduced $16 \%$ of energy use emissions and $10 \%$ of total life cycle emissions. BEnS emission reduction at the energy use stage was $25 \%$ and total emission reduction $10 \%$. It is interesting to note that the HRV21 scenario performs better than BEnS, although the scenario has a poorer energy performance. This is due to the increased emissions from building materials and the construction process.

Figure 3 shows the acidification potential savings for the different scenarios compared with the original building. In terms of GWP, most savings relate to the energy use stage and the most negative 
impact are from materials and construction processes. DEERS saved $41 \%$ of $\mathrm{SO}_{2}$ eq at the energy use stage and $13 \%$ on the total life cycle. HRV 21 saved $23 \%$ on energy use and $16 \%$ on total life cycle, HRV22.7 saved $16 \%$ on energy use and $11 \%$ in total and BEnS saved $26 \%$ on energy use and $6 \%$ on total life cycle.

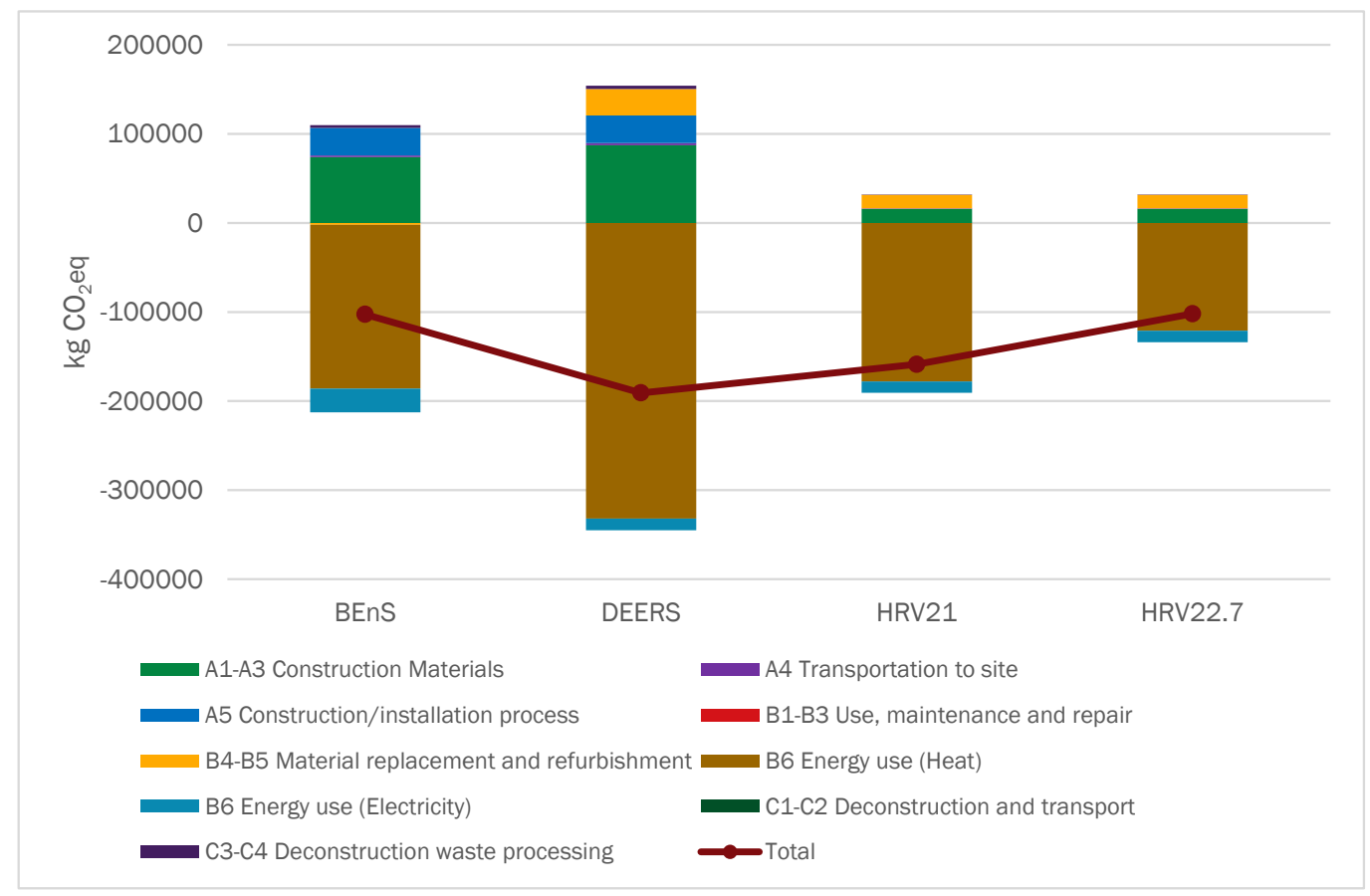

Figure 2. Global warming potential $\left(\mathrm{CO}_{2} \mathrm{eq}\right)$.

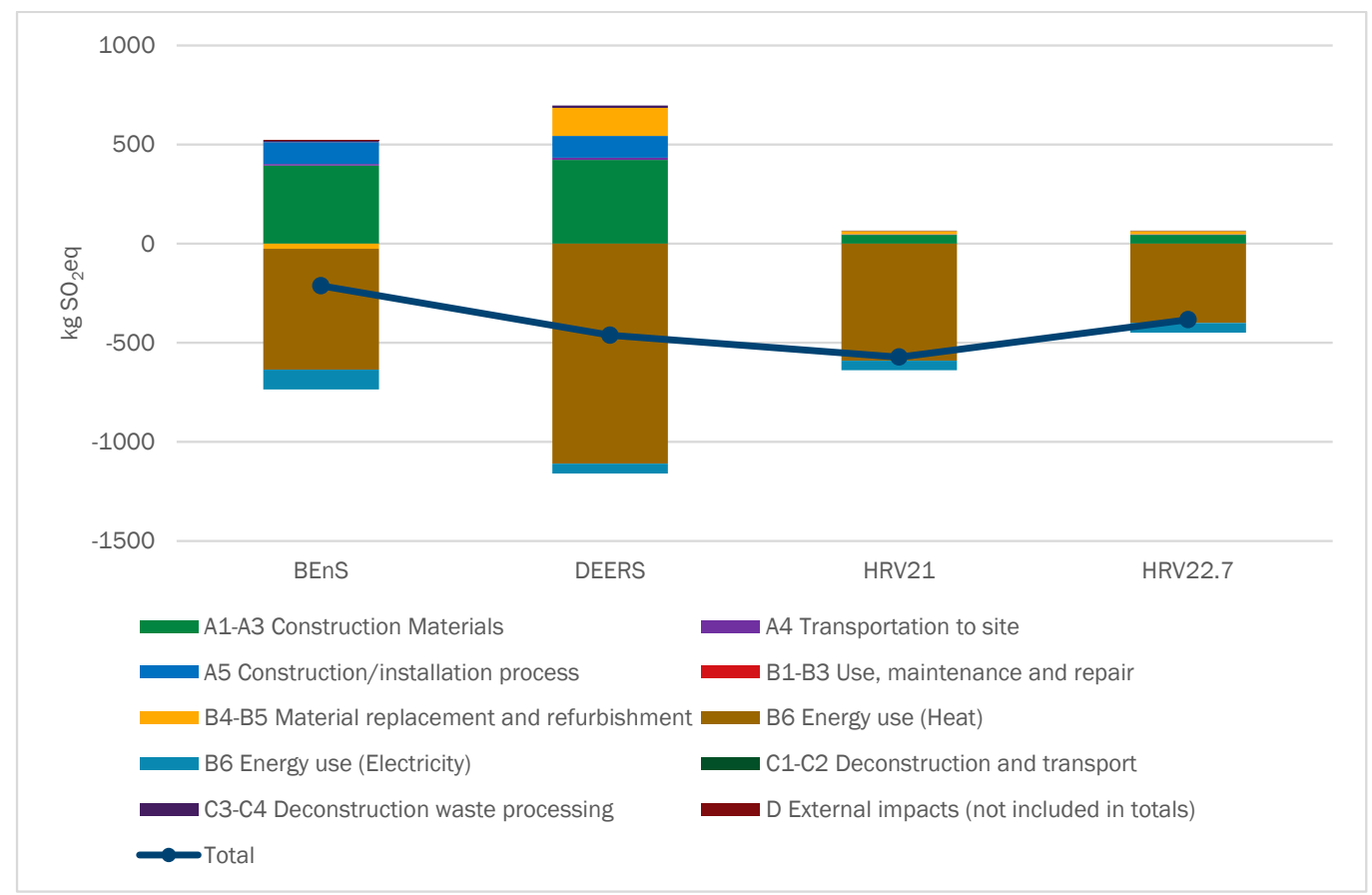

Figure 3. Acidification potential $\left(\mathrm{SO}_{2} \mathrm{eq}\right)$.

In Figure 4, it is possible to observe a trend similar to other categories, where DEERS and BEnS performed best for the energy use category. This performance does not compensate for the impact of the material and the construction process. DEERS saved $42 \%$ of $\mathrm{PO}_{4} \mathrm{eq}$ at the energy use stage and $13 \%$ 
on the total life cycle. HRV21 saved $23 \%$ on energy use and $17 \%$ on total life cycle, HRV22.7 saved $16 \%$ on energy use and $11 \%$ in total and BEnS saved $25 \%$ on energy use and $5 \%$ on total life cycle.

Figure 5 shows the impacts on resource use for the renovation scenarios. As shown by previous categories, the most positive effect related to energy use during the life cycle. DEERS saved $43 \%$ of Sbeq at the energy use stage and $11 \%$ on the total life cycle. HRV21 saved $23 \%$ of energy use and $12 \%$ on the total life cycle, HRV22.7 saved $16 \%$ on energy use and $8 \%$ in total. BEnS saved $24 \%$ on energy use and $3.5 \%$ on total life cycle.

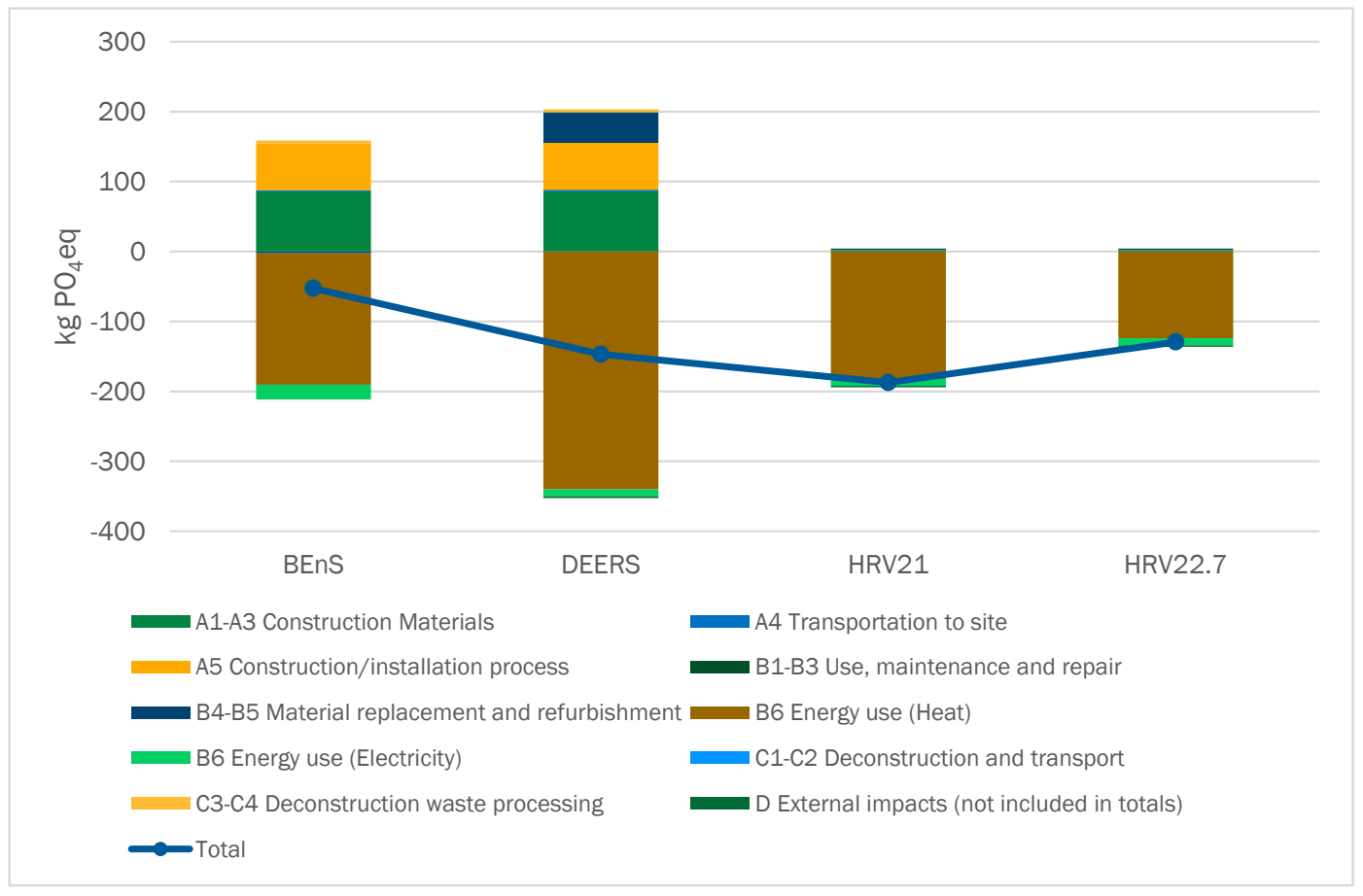

Figure 4. Eutrophication potential $\left(\mathrm{PO}_{4} \mathrm{eq}\right)$.

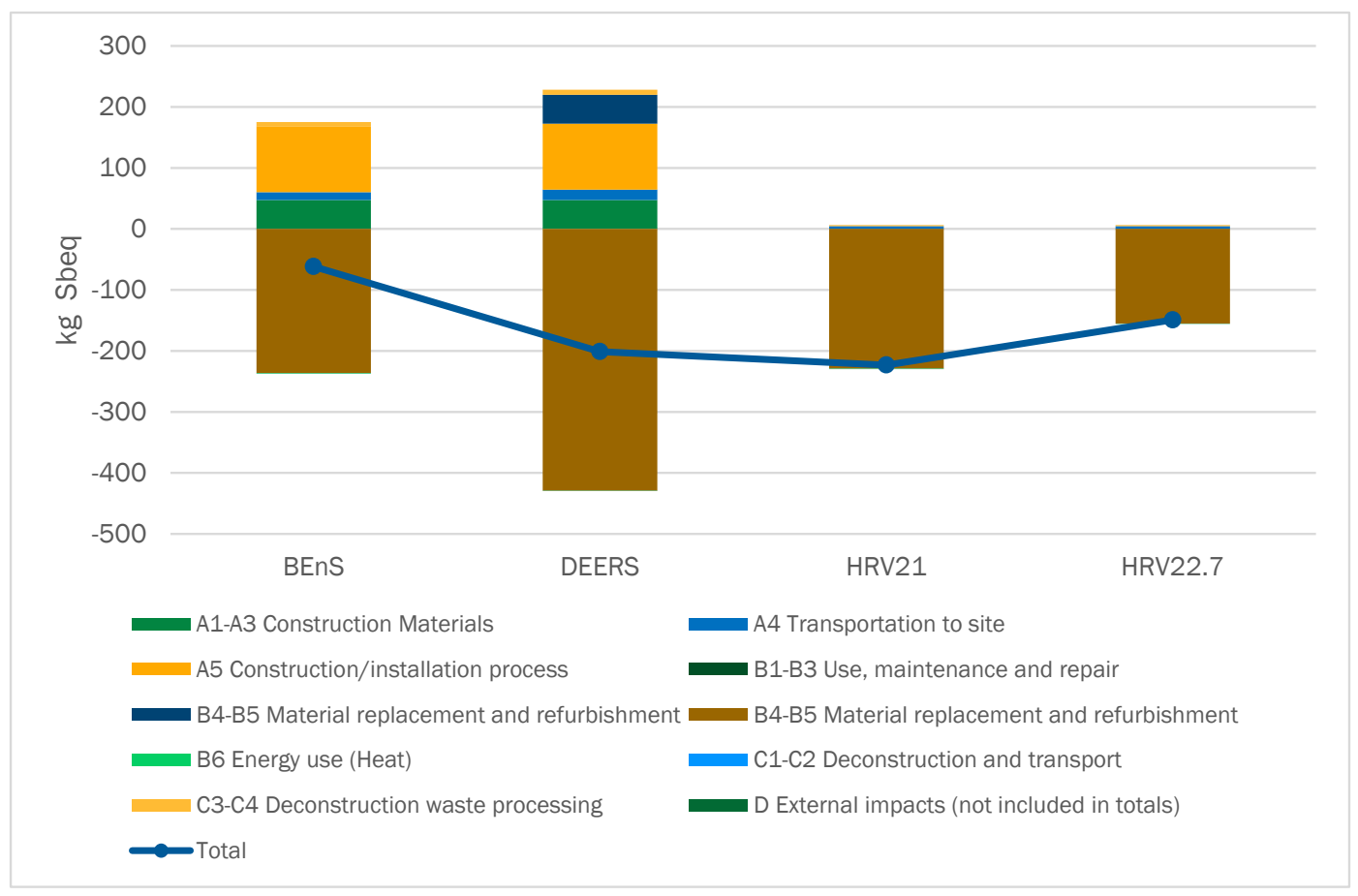

Figure 5. Abiotic depletion potential of non-fossil elements (Sbeq). 
Considering all impacts, the stage that contributes most was the operational energy use, followed by construction and installation processes and building materials. It is noteworthy that material transport showed a smaller contribution to life cycle impact, due to the availability of local products.

As seen in Figure 6, based on the LCA, BEnS was the scenario with the highest overall impact in all categories. The total environmental impact was relative to the highest sum (in percent). It shows that HRV 22.7 followed the worst-case scenario. HRV21 was in three categories, the scenario with less environmental impact. DEERS was the best-case scenario when it comes to GWP.

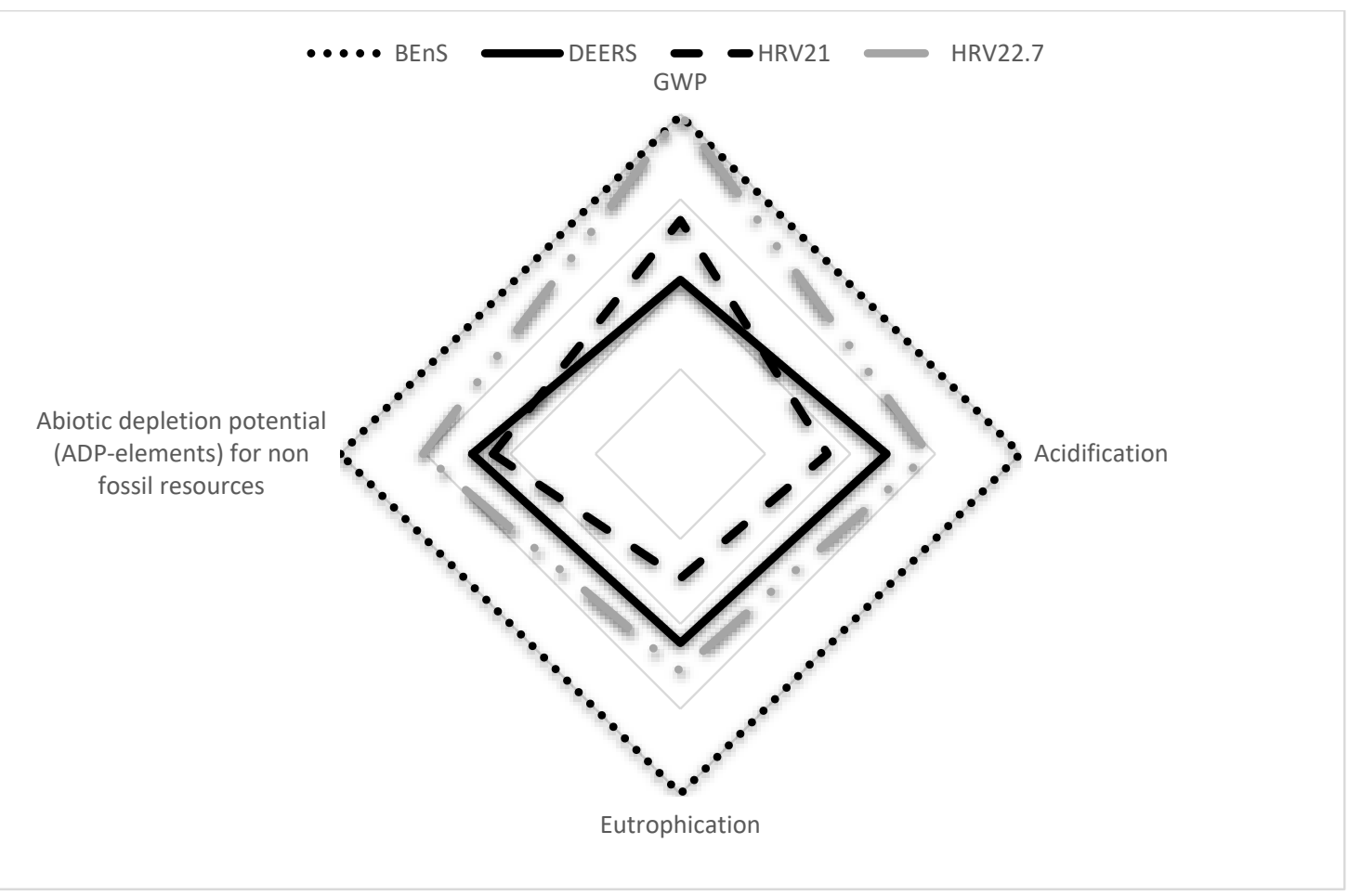

Figure 6. Life cycle assessment (LCA) results in percent.

\section{Discussion}

\subsection{About the Results}

With regard to environmental impact during the life cycle of the different alternatives, it is interesting to note that different methods can archive a similar overall environmental impact. In the case of DEERS, the approach is to improve the building envelope and to replace the ventilation system with an HRV. It reduces energy use by about 50\%. The HRV21 approach keeps the building envelope as it is and focuses on the installation of an HRV. It can theoretically increase the thermal comfort in the building and reduce overall energy use by about $28 \%$. The environmental impact of the materials and construction process for these two approaches is interesting. DEERS can counteract the environmental benefits of reducing energy use and get a similar overall performance as HRV21.

Given that, HRV21 has a lower impact during the construction process and the choice of material. It is the "low-hanging fruit". That perspective depends on the assumption that the sources of energy in the municipality will not change over the next 50 years (which is extremely unlikely). For a further elaboration of this result, see Section "Time perspective" below.

The situation of the Swedish energy system represents a unique situation. DH in Sweden, and in this case, Borlänge municipality, consists of fuels that have low fossil carbon content. The discussion about how this can affect the future of buildings is problematic; reducing the use of DH would increase the use of electricity. In this study, the source for electricity was renewables. In reality, when temperature drops, the use of electricity in HRV is higher. Because of these electric peaks, there is 
a need for fossil fuels; to a large extent coal and LPG. In this study, that is not considered. Here an average electricity mix was considered.

\subsection{About the Methodology}

\subsubsection{Uncertainty}

It is important to note that the LCA method does not allow the benefits and loads, beyond system boundaries (D), to be calculated in the overall results. This is due to the uncertainty that future users and practitioners will recycle the various materials used in the renovation of the building. In this study, these benefits would have an insignificant impact. However, projects that have a larger share of recyclable materials would hide better environmental performance, due to the uncertainty.

With regard to the selection of DH data, the selected software allows only the use of externally certified data, which provides a very limited amount of possibilities. Analysing the data from different energy companies about the energy mix concluded that the "best possible" verified data was from Göteborg municipality. Moreover, the share of fossil fuels was greater and the amount of biofuels was lower. This can lead to the GWP effect for DH usage (B6 heat) being about $84 \%$ of the resulting impact. However, since the tool is for commercial use, modification of data is not optional.

The sensitivity analysis performed assumed different life span and material alternatives. In the selected LCA tool, it is not possible to specify where the material is from. Available data sets are from the EPDs that companies themselves have made. The program makes a "compensation for local conditions" based on statistical data on energy intensity to produce similar products, as in the studied country. Consequently, the result consists of considerable uncertainties.

\subsubsection{Time Perspectives}

By combining an LCA approach with the method developed by Lidberg et al. [30], the system boundary for the entire system will extend and take into account a life cycle approach of the building materials and energy use. One of the limitations is the time span. Considering the sources of energy, the configuration of today is unrealistic. The introduction of more renewable energy sources in the energy mix over the next 50 years and the development of a 4th generation DH in Sweden will have a significant impact on the GWP results.

It is important to discuss how the life span of different materials can differ from theory to reality. A well-known condition is that manufacturers (such as window manufacturers) define the life span of their products as the product's technical service life before it starts to reduce performance. Building owners however, often use a commercial life span. One consequence is that the replacement of materials and installation will not be according to the manufacturer's recommendation, but instead when it is broken or commercial life at the earliest. In this perspective, LCA is problematic. This study took into consideration the technical life of the product (defined by manufacturers). However, it is well-known in the construction and real estate industry that building owners do not change components on their buildings until it is ultimately necessary, which means that the building's energy performance can change over time.

Another aspect is that life expectancy varies between different construction products. For a given reference period, some may be relatively new, while others will be replaced at the end of the study period. To solve the problem, the software interpolates LCA data for the components. By performing such interpolations, the EN15978 standard is not meet. This can make the assessment skew and the choice of reference study can change the results. Perhaps the standard is the main problem, instead of the software. The significance of this issue requires further investigation.

\subsubsection{Type of LCA}

As described above, this study follows the standard EN 15978, which means that an attribution LCA is considered. However, when comparing different renovation strategies, it makes it useful for 
making decisions, which suggests that it is a consequential LCA. In addition, the study life span of 50 years means long-term accounting.

The ILCD handbook [41] describes three main goal situations that occur in LCA practice. Situation A ("Micro level decision support") defined as "limited or no structural consequences outside the decision-context". Situation A is in line with the standard and the OneClickLCA software. Situation B ("Meso/macro level decision support") is expected to have structural consequences beyond the decision-making framework. Additionally, it is stated, "the analysed systems shall be modelled as in Situation A, except for those processes in the background system that are affected by large-scale consequences of the analysed decision. These are modelled with the mix of the long-term marginal processes/systems." LCA as such only covers renovation measures for one building, which of course would not cause changes in the DH system. However, with the proposed methodology [30], a combined assessment of renovation in residential areas and related changes in the energy DH system is suggested. From this perspective, when expanded to a solely residential area, categorization as Situation B may be appropriate. In addition, the long period of 50 years entails long-term changes in the background system to be included. With this approach, a suggestion is energy system models to calculate the marginal mix. It would of course increase the uncertainty in the assessment, as there is real uncertainty about how these systems will actually change. Working with future scenarios would then be more feasible, showing various plausible outcomes.

Many of the previous studies [42] use a consequential approach for assessing and evaluating changes in energy use in buildings. This may be based on a misunderstanding, as most of these studies refer to situation A above. However, the energy systems research field widely uses the marginal perspective. Studies are mostly for finding short-term consequences, which typically use carbon or oil as a marginal energy source. It seems that building designers, as well as researchers in energy systems and LCA, still have some work to do to conform recommendations and practice in how to perform these assessments. There is some previous work addressing these issues [42-44] but there is yet more work to do in this area.

\subsubsection{Applicability}

One of the advantages of the chosen software is the possibility to perform a detailed analysis with limited data, and as the software is cloud-based, it is possible to see the changes immediately. The tool aims to have building companies using it to assess the environmental impact of the project during the design stage or to use it to communicate environmental benefits with their operations.

The tool has several shortcomings. These require further discussion and possible improvements. As mentioned earlier, these include handling of varying life spans that is not accrual, and environmental impacts treated differently from economic assessments. There is currently no option to using the tool with a consequential approach and long service life combined with short-term data. In addition, there is only one specific impact assessment method, which makes it less applicable to use by LCA practitioners. There is no possibility of changing the dataset of materials and processes. Sometimes it makes it necessary to customize the information for "best" available. It is obvious that the chosen LCA tool has limitations for research purposes due to the commercial intent.

Although LCA and energy use projects can aid stakeholders in the building decision-making process, completing the analysis with a life cycle cost (LCC) assessment in order to assess which renovations are more desirable in the life cycle perspective is highly recommended. In order to complete the method proposed by Lidberg et al. [29], it is necessary to combine the LCA approach with a LCC analysis. This makes it possible to assess the desired investment from the decision maker's point of view.

\section{Conclusions}

In this study, we report the results of the LCA environmental impact for a set of renovation scenarios for a residential building in Borlänge, Sweden. An important aspect is that the energy system 
in Sweden has a special situation. Primarily, the electricity supply constitutes renewable sources and nuclear power. In addition, the investigated building used DH for space heating and domestic hot water preparation. Still, sustainable strategies are important. The LCA focus was on four selected environmental categories; GWP, AP, EP and ADP.

The study had two goals. The first focused on how scenarios can affect the environmental impact of the life cycle in terms of materials and operational energy use. The second objective was to identify and discuss how the different life cycle stages contribute to the overall environmental impact of these renovation strategies.

In this study, the results of scenarios based on HRV, with temperature reduction (HRV22.7) and without temperature reduction (HRV21) were effective, defined as "low-hanging fruit". They contributed significant improvements in the LCA results. The effect of HRV21 was similar to the scenarios with limited (BENS) or extensive building material changes (DEERS).

An important aspect of the results is the assumption that the energy system will remain the same during the study period, in this case 50 years. If the perspective of predominant renewable energy is changed, it may be more relevant to change building materials. In addition to the energy mix, major uncertainties concern the definition of system boundaries and estimates of EPD. Time perspective is another important methodological aspect. Modelled duration, as well as the difference between commercial and technical life expectancy is also essential. The tool used in thus study had several shortcomings associated with uncertainty, such as the possibility of simulating different life spans, time variations in the energy mix, etc. For the future, there is a need for additional work with scenarios based on extensive model development. Furthermore, combining the LCA approach with a LCC analysis could improve the analysis.

Author Contributions: Conceptualization, R.R.-V., O.E. and T.O.; Formal analysis, R.R.-V., O.E. and T.O.; Investigation, R.R.-V.; Methodology, R.R.-V. and O.E.; Software, R.R.-V.; Supervision, O.E. and T.O.; Validation, R.R.-V.; Visualization, R.R.-V.; Writing-original draft, R.R.-V., O.E. and T.O.; Writing-review \& editing, R.R.-V., O.E. and T.O.

Funding: This work was carried out under the auspices of the industrial post-graduate school Reesbe, which is financed by the Knowledge Foundation (KK-stiftelsen) and Byggpartner i Dalarna AB.

Acknowledgments: The authors would specially like to acknowledge Kristian Haglund from ByggPartner i Dalarna $\mathrm{AB}$, for contributing with his professional advice.

Conflicts of Interest: The authors declare no conflict of interest.

\section{References}

1. European Commission. Communication from the Commission to the European Parliament and The Council. Energy Efficiency and Its Contribution to Energy Security and the 2030 Framework for Climate and Energy Policy; European Commission: Brussels, Belgium, 2014.

2. European Commission. Buildings-European Commission. Available online: https://ec.europa.eu/energy/ en/topics/energy-efficiency/buildings (accessed on 13 May 2015).

3. Toller, S.; Wadeskog, A.; Finnveden, G.; Malmqvist, T.; Carlsson, A. Energy Use and Environmental Impacts of the Swedish Building and Real Estate Management Sector. J. Ind. Ecol. 2011, 15, 394-404. [CrossRef]

4. Vilches, A.; Garcia-Martinez, A.; Sanchez-Montã, B. Life cycle assessment (LCA) of building refurbishment: A literature review. Energy Build. 2017, 135, 286-301. [CrossRef]

5. Botta, M. Towards Sustainable Renovation Three Research Projects; Royal Institute of Technology: Stockholm, Sweden, 2005.

6. Swedish Energy Agency. Energy in Sweden 2015-An Overall Picture of the Energy Situation in Sweden, 2015. Available online: www.energimyndigheten.se (accessed on 3 February 2017).

7. Akander, J.; Cehlin, M.; Moshfegh, B. Assessing the Myths on Energy Efficiency When Retrofitting Multifamily Buildings in a Northern Region. In Sustainable High Rise Buildings in Urban Zones: Advantages, Challenges, and Global Case Studies; Sayigh, A., Ed.; Springer International Publishing: Cham, Switzerland, 2017; pp. 139-161, ISBN 978-3-319-17756-4. 
8. Gustafsson, M.S.; Gustafsson, M.; Myhren, J.A.; Dotzauer, E. Primary energy use in buildings in a Swedish perspective. Energy Build. 2016, 130, 202-209. [CrossRef]

9. Lidberg, T.; Olofsson, T.; Trygg, L. System impact of energy efficient building refurbishment within a district heated region. Energy 2016, 106, 45-53. [CrossRef]

10. Stenberg, E. Essays: Revisiting Sweden's Million Program Era: Contemporary Design Strategies for Prefabricated Structural Systems. In Small Interventions: New Ways of Living in Post-War Modernism, 1st ed.; Birkhäuser Verlag: Basel, Switzerland, 2016; pp. 107-114.

11. Buildings Performance Institute Europe (BPIE). Europe's Buildings under the Microscope; Buildings Performance Institute Europe: Bruxelles, Belgium, 2011.

12. Anand, C.K.; Amor, B. Recent developments, future challenges and new research directions in LCA of buildings: A critical review. Renew. Sustain. Energy Rev. 2017, 67, 409-416. [CrossRef]

13. Rønning, A.; Brekke, A. Life cycle assessment (LCA) of the building sector: Strengths and weaknesses. In Eco-Efficient Construction and Building Materials; Elsevier: Amsterdam, The Netherlands, 2014; pp. 63-83. [CrossRef]

14. Dekkiche, H.; Taileb, A. ScienceDirect The Importance of Integrating LCA into the LEED Rating System. Procedia Eng. 2016, 145, 844-851. [CrossRef]

15. LCA-Baserade Miljökrav i Byggandet. Available online: https://www.ivl.se/download/18. 2aa2697816097278807db14/1520579019127/C285.pdf (accessed on 25 May 2018).

16. Swedish Green Building Council. Om Miljöbyggnad. Available online: http://www.sgbc.se/ommiljoebyggnad (accessed on 17 April 2015).

17. Reza, B.; Sadiq, R.; Hewage, K. Emergy-based life cycle assessment (Em-LCA) of multi-unit and single-family residential buildings in Canada. Int. J. Sustain. Built Environ. 2014, 3, 207-224. [CrossRef]

18. Cabeza, L.F.; Rincón, L.; Vilariño, V.; Pérez, G.; Castell, A. Life cycle assessment (LCA) and life cycle energy analysis (LCEA) of buildings and the building sector: A review. Renew. Sustain. Energy Rev. 2014, 29, $394-416$. [CrossRef]

19. Gustavsson, L.; Joelsson, A. Life cycle primary energy analysis of residential buildings. Energy Build. 2010, 42, 210-220. [CrossRef]

20. Wallhagen, M.; Glaumann, M.; Malmqvist, T. Basic building life cycle calculations to decrease contribution to climate change-Case study on an office building in Sweden. Build. Environ. 2011, 46, 1863-1871. [CrossRef]

21. Mjörnell, K.; Boss, A.; Lindahl, M.; Molnar, S. A Tool to Evaluate Different Renovation Alternatives with Regard to Sustainability. Sustainability 2014, 6, 4227. [CrossRef]

22. Skullestad, J.L.; Bohne, R.A.; Lohne, J. High-rise Timber Buildings as a Climate Change Mitigation Measure-A Comparative LCA of Structural System Alternatives. Energy Procedia 2016, 96, 112-123. [CrossRef]

23. Lasvaux, S.; Favre, D.; Périsset, B.; Bony, J.; Hildbrand, C.; Citherlet, S. Life Cycle Assessment of energy related building renovation: Methodology and case study. Energy Procedia 2015, 78, 3496-3501. [CrossRef]

24. Dodoo, A.; Gustavsson, L.; Sathre, R. Life cycle primary energy implication of retrofitting a wood-framed apartment building to passive house standard. Resour. Conserv. Recycl. 2010, 54, 1152-1160. [CrossRef]

25. Häfliger, I.-F.; John, V.; Passer, A.; Lasvaux, S.; Hoxha, E.; Saade, M.R.M.; Habert, G. Buildings environmental impacts' sensitivity related to LCA modelling choices of construction materials. J. Clean. Prod. 2017, 156, 805-816. [CrossRef]

26. Roux, C.; Schalbart, P.; Assoumou, E.; Peuportier, B. Integrating climate change and energy mix scenarios in LCA of buildings and districts. Appl. Energy 2016, 184, 619-629. [CrossRef]

27. Schlanbusch, R.D.; Fufa, S.M.; Häkkinen, T.; Vares, S.; Birgisdottir, H.; Ylmén, P. Experiences with LCA in the Nordic building industry-Challenges, needs and solutions. Energy Procedia 2016, 96, 82-93. [CrossRef]

28. Wijnants, L.; Allacker, K.; de Troyer, F. Environmental and Financial Life Cycle Assessment of 'Open-renovation-systems': Methodology and Case Study. Energy Procedia 2016, 96, 529-539. [CrossRef]

29. Oviir, A.; Trinius, W.; Peters, I. Life cycle assessment (LCA) in the framework of the next generation Estonian building standard Building certification as a strategy for enhancing sustainability. Energy Procedia 2016, 96, 351-362. [CrossRef]

30. Lidberg, T.; Ramírez-Villegas, R.; Olofsson, T.; Eriksson, O. An approach to illustrate strategies for improved energy efficiency at the municipal level. In Proceedings of the 14th International Symposium on District Heating and Cooling, Stockholm, Sweden, 6-10 September 2014; pp. 5-10. [CrossRef] 
31. Ramírez-Villegas, R.; Eriksson, O.; Olofsson, T. Assessment of renovation measures for a dwelling area-Impacts on energy efficiency and building certification. Build. Environ. 2016, 97, 26-33. [CrossRef]

32. ISO 14040:2006(en). Environmental Management-Life Cycle Assessment_Principles and Framework. Available online: https:/ /www.iso.org/obp/ui/\#iso:std:iso:14040:ed-2:v1:en (accessed on 22 May 2018).

33. EN 15978. Sustainability of Construction Works-Assessment of Environmental Performance of Buildings-Calculation Method. 2012; p. 56. Available online: https://standards.cen.eu/dyn/www /f?p= 204:110:0::::FSP_PROJECT,FSP_ORG_ID:31325,481830\&cs=1A484AD7BE5ADA98EFFF4A6274ECA36E8 (accessed on 15 May 2018).

34. Zinko, H. Building refurbishment to passive house standards of the quarter Brogården in Alingsås, Sweden. In Proceedings of the World Renewable Energy Congress, Linkoping, Sweden, 8-13 May 2011; pp. 8-13.

35. Varsam Energieffektiv Renovering TJÄRNA Ängar-E2B2. Available online: http://www.e2b2. se/forskningsprojekt-i-e2b2/renovering/varsam-energieffektiv-renovering-tjaerna-aengar/ (accessed on 22 May 2018).

36. LCA and Generic Features-One Click LCA ${ }^{\circledR}$ Software. Available online: https://www.oneclicklca.com/ support/customer-support/premium-calculations/ (accessed on 22 May 2018).

37. EQUA. Use Manual IDA Indoor Climate and Energy, Stockholm, 2013. Available online: http://www. equaonline.com/iceuser/pdf/ICE45eng.pdf (accessed on 17 April 2015).

38. Miljövärdering av fjärrvärme-Energiföretagen Sverige. Available online: https://www.energiforetagen.se/ statistik/fjarrvarmestatistik/miljovardering-av-fjarrvarme/ (accessed on 22 May 2018).

39. Pachauri, R.K.; Meyer, L.; Ypersele, J.-P.V.; Brinkman, S.; Kesteren, L.V.; Leprince-Ringuet, N.; Boxmeer, F.V. Climate Change 2014 Synthesis Report The Core Writing Team Core Writing Team Technical Support Unit for the Synthesis Report, Russ. Fed. Hoesung Lee (Republic Korea) Scott B. Power N.H. Ravindranath. Available online: https://www.ipcc.ch/pdf/assessment-report/ar5/syr/SYR_AR5_FINAL_full_wcover.pdf (accessed on 22 May 2018).

40. Rockström, J.; Steffen, W.; Noone, K.; Persson, Å.; Iii, F.S.C.; Lambin, E.; Lenton, T.M.; Scheffer, M.; Folke, C.; Schellnhuber, H.J.; et al. Planetary Boundaries Exploring the Safe Operating Space for Humanity. Ecol. Soc. 2009, 14. Available online: http:/ / www.jstor.org/stable/26268316 (accessed on 25 May 2018). [CrossRef]

41. European Commission, Joint Research Centre, Institute for Environment and Sustainability. International Reference Life Cycle Data System (ILCD) Handbook—General Guide for Life Cycle Assessment_Detailed Guidance; European Commission: Brussels, Belgium, 2010. [CrossRef]

42. Buyle, M.; Braet, J.; Audenaert, A. Life cycle assessment of an apartment building: Comparison of an attributional and consequential approach. Energy Procedia 2014, 62, 132-140. [CrossRef]

43. Miller, T.R.; Gregory, J.; Kirchain, R. Critical Issues When Comparing Whole Building \& Building Product Environmental Performance. 2016; p. 31. Available online: http:/ /hdl.handle.net/1721.1/104838 (accessed on 28 May 2018).

44. Gantner, J.; Wittstock, B.; Lenz, K.; Fischer, M.; Sedlbauer, K. EeBGuide Guidance Document Part B: Buildings, Fraunhofer Verlag, 2015. Available online: https:/ / books.google.se/books?id=V0IeswEACAAJ (accessed on 25 May 2018).

(C) 2019 by the authors. Licensee MDPI, Basel, Switzerland. This article is an open access article distributed under the terms and conditions of the Creative Commons Attribution (CC BY) license (http://creativecommons.org/licenses/by/4.0/). 